\title{
PEMANFAATAN BIJI KETAPANG (Terminalia catappa) SEBAGAI SUMBER PROTEIN DAN SERAT PADA PRODUK MAKANAN STIK
}

\author{
Eman Darmawan ${ }^{1}$
}

\begin{abstract}
The purpose of this study was to determine the effect of substitution ketapan seed to chemical and organoleptic properties of the resulted snack food, knowing the exact level of substitution, so obtain the snack food liked the panelists. The design used in this study was completely randomized design (CRD) with single factor that influences the concentration of seed flour substitution ketapan seed consisting of 5 treatments. Each treatment be repeated 3 times. The data obtained was analyzed by Analysis of Variance (ANOVA), if there was a difference between the treatment of advanced test conducted by Duncan`s Multiple Ranges Test Method (DMRT) at the level of 5\%. Substitution of wheat flour with ketapan seed flour affects the snack food produced, which can reduce the water content of the snack food and increase levels of protein and fiber snack food. Ketapan seed flour substitution preferred by the panelists was substitution ketapan seed flour up to $30 \%$ with a value of 3.52 and the criteria snack food produced had a water content of $3.67 \%, 15.10 \% \mathrm{db}$ protein content, fiber content of $3.64 \% \mathrm{db}$, brownish yellow color (2.95), a rather tasted wheat flour (3.35), and crispy (3.60).
\end{abstract}

Keywords: Ketapan seed, stik, protein

\begin{abstract}
ABSTRAK
Tujuan penelitian ini adalah untuk mengetahui pengaruh substitusi biji ketapang terhadap sifat kimia dan organoleptik stik yang dihasilkan, mengetahui tingkat substitusi yang tepat, sehingga dihasilkan stik yang disukai panelis. Rancangan yang digunakan dalam penelitian ini adalah Rancangan Acak Lengkap (RAL) dengan faktor tunggal yaitu pengaruh konsentrasi substitusi tepung biji ketapang yang terdiri dari 5 perlakuan. Tiap perlakuan dilakukan pengulangan sebanyak 3 kali. Data yang diperoleh dilakukan Analisis of Varians (ANAVA), apabila terdapat perbedaan antara perlakuan dilakukan uji lanjutan dengan Metode Duncan`s Multiple Ranges Test (DMRT) pada jenjang 5\%. Substitusi tepung terigu dengan tepung biji ketapang berpengaruh terhadap stik yang dihasilkan, yaitu dapat menurunkan kadar air stik dan meningkatkan kadar protein dan serat stik. Substitusi tepung biji ketapang yang masih disukai oleh panelis adalah sampai pada subtitusi tepung biji ketapang 30\% yaitu dengan nilai 3,52 dan kriteria stik yang dihasilkan mempunyai kadar air 3,67 \%, kadar protein 15,10 \%db, kadar serat 3,64 \%db, warna kuning kecoklatan $(2,95)$, agak terasa tepung terigu $(3,35)$, dan renyah $(3,60)$.
\end{abstract}

Kata kunci : biji ketapang, stik, protein

\section{PENDAHULUAN}

Ketapang atau katapang (Terminalia catappa) adalah nama sejenis pohon tepi pantai yang rindang. Ketapang saat ini banyak digunakan sebagai pohon peneduh di taman-taman dan tepi jalan, sehingga buahnya/biji ketapang banyak berserakan di taman-taman/tempat parkiranbelum dimanfaatkan secara maksimal oleh masyarakat. Pemanfaatan biji ketapang masih minim karena masyarakat belum mengetahui biji ketapang memiliki gizi yang tinggi, sehingga selama ini biji ketapang hanya menjadi sampah organik. Menurut Lia, dkk., (2010) biji ketapang memiliki rasa yang gurih dan kandungan gizinya tinggi antara lain: protein $(25,3 \%)$, gula $(16 \%)$, serat $(11,75 \%)$, karbohidrat $(5,8 \%)$.

Tingginya kandungan protein dan serat pada biji ketapang merupakan suatu potensi yang dapat dimanfaatkan sebagai bahan baku ataupun bahan tambahan pada produk makanan sebagai upaya meningkat kandungan gizi dan sifat fungsionalnya karena masih banyak produkproduk makanan yang beredar di pasaran hanya tinggi kandungan gizi tertentu misalnya tinggi karbohidrat ataupun lemak tetapi rendah protein dan rendah sifat fungsionalnya. Tentunya hal ini

\footnotetext{
${ }^{1}$ Program Studi Teknologi Pangan Fakultas Teknologi Pertanian Universitas Widya Mataram Yogyakarta 冈e_dmwn@yahoo.com
} 
dapat berdampak kurang baik bagi konsumen apabila mengkonsumsi produk tersebut secara terus menerus karena dapat mengakibatkan kekurangan asupan protein (malnutrisi), sedangkan dampak kekurangan serat dapat menggangu sistem pencernaan dan dapat memacu timbulnya penyakit degeneratif seperti kolesterol, diabetes dan jantung.

Produk makanan yang tinggi karbohidrat dan rendah protein biasanya adalah makanan ringan (snack food) salah satunya adalah stik.Stik merupakan makanan yang banyak disukai oleh masyarakat, bersifat kering, renyah (crispy) berbentuk batang memanjang dengan ukuran $1 \mathrm{x}$ $10 \mathrm{~cm}$ dan ketebalan $3 \mathrm{~mm}$. Stik merupakan bahan makanan yang terbuat dari tepung terigu. Tepung terigu merupakan bahan bakunya gandum yang sampai saat ini masih harus impor, sehingga pemanfatan biji ketapang sebagai bahan baku untuk pembuatan stik selain dapat meningkatkankandungan protein dan serat stik, juga dapat mengurangi ketergantungan impor gandum apabila penggunaanya secara terus menerus.

Akan tetapi karena adanya perbedaan kandungan gizi antara biji ketapang dengan tepung terigu, maka substitusi tepung terigu dengan biji ketapang dapat mempengaruhi sifat kimia dan organoleptik stik yang dihasilkan. Oleh karena itu perlu dilakukan penelitian lebih lanjut mengenai pengaruh tingkat substitusi tepung terigu dengan biji ketapang terhadap sifat kimia dan organoleptik stik yang dihasilkan.

Penelitian ini bertujuan untuk mengetahui pengaruh substitusi biji ketapang terhadap sifat kimia dan organoleptik stik yang dihasilkan, serta mengetahui tingkat substitusi optimal yang menghasilkan stik disukai konsumen.

\section{METODE PENELITIAN}

\section{Bahan dan alat}

Bahan utama yang digunakan dalam penelitian ini adalah tepung terigu merek Segitiga produksi PT. Bogasari, biji ketapang, garam dapur, soda kue, telur dan minyak goreng diperoleh dari Pasar Ngasem Yogyakarta. Bahan untuk analisa kimia PA produk E. Merck antara lain: ether, katalisator $\mathrm{Na}_{2} \mathrm{SO}_{4}-\mathrm{HgO} \quad(20: 1)$,
$\mathrm{NaOH}-\mathrm{Na}_{2} \mathrm{~S}_{2} \mathrm{O}_{3}, \mathrm{H}_{2} \mathrm{SO}_{4}$ pekat, $\mathrm{K}_{2} \mathrm{SO}_{4} 10 \%$, larutan $\mathrm{NaOH}$, larutan $\mathrm{H}_{2} \mathrm{SO}_{4}(93-98 \%$ bebas N), BCGMR, HCL 0.02 N, Glukosa, aquades.

Alat yang digunakan dalam penelitian ini adalah timbangan, baskom plastik, wajan, termotemer, pengaduk, gilingan, peralatan gelas, alat destilasi, labu Kjeldal, Erlenmeyer, dan alat uji sensoris.

\section{Pelaksanaan penelitian}

\section{Pembuatan tepung biji ketapang}

Biji Ketapang dihilangkan kulitnya terlebih dahulu, dikeringkan menggunakan alat pengering kabinet pada suhu $50{ }^{\circ} \mathrm{C}$ selama 48 jam. Selama pengovenan biji ketapang harus dibalik secara kontinyu, agar panas merata. Biji ketapang kering selanjutnya dilakukan penepungan/penggilingan dan untuk memperoleh ukuran tepung yang seragam kemudian di saring dengan menggunakan penyaring ukuran 60 mesh.

\section{Pembuatan stik}

Proses pembuatan stik diawali dengan penimbangan masing-masing bahan penyusun stik.Komposisi bahan-bahan dalam pembuatan adonan stik seperti tercantum dalam Tabel 1.

Tabel 1. Komposisi adonan stik pada berbagai perbandingan tepung terigu dan tepung biji ketapang

\begin{tabular}{cccccc}
\hline Komponen & $\mathrm{K}$ & $\mathrm{A}$ & $\mathrm{B}$ & $\mathrm{C}$ & $\mathrm{D}$ \\
\cline { 2 - 6 } & $0 \%$ & $10 \%$ & $20 \%$ & $30 \%$ & $40 \%$ \\
\hline $\begin{array}{c}\text { Tepung } \\
\text { biji } \\
\text { ketapang } \\
\quad \text { (g) }\end{array}$ & 0 & 40 & 80 & 120 & 160 \\
$\begin{array}{c}\text { Tepung } \\
\text { terigu (g) } \\
\text { Telur } \\
\text { (butir) }\end{array}$ & 400 & 360 & 320 & 280 & 240 \\
$\begin{array}{c}\text { Garam (g) } \\
\text { Soda kue } \\
\text { (g) }\end{array}$ & 10 & 10 & 10 & 10 & 10 \\
Air (ml) & 100 & 100 & 100 & 100 & 100 \\
\hline
\end{tabular}

\section{Rancangan percobaan}

Penelitian ini dilakukan dengan metodeRancangan Acak Lengkap (RAL) dengan 
faktor tunggal yaitu pengaruh konsentrasi substitusi tepung biji ketapang yang terdiri dari 5 perlakuan.Tiap perlakuan dilakukan pengulangan sebanyak 3 kali. Masing-masing stik yang dihasilkan dianalisa secara kimia (kadar air, kadar protein dan kadar serat kasar) dan uji organoleptik dilakukan dengan uji perbedaan (different test) metode scoring meliputi warna, rasa, kerenyahan dan uji hedonic (kesukaan keseluruhan). Data yang diperoleh dianalisa varian (ANOVA), apabila terdapat perbedaan nyata, dilakukan uji lanjutan dengan metode Duncan's Multiple Range Test (DMRT) pada taraf signifikasi $5 \%$.

\section{Hasil analisa biji ketapang}

Biji ketapangsebagai bahan yang akandigunakan untuk substitusi dengan tepung terigu terlebih dahulu dilakukan analisa kimia, yaitu meliputi analisa kadar air, protein dan serat. Hasil analisa tersebut dapat dilihat pada Tabel 2.

Tabel 2. Hasil analisa biji ketapang

\begin{tabular}{ll}
\hline \multicolumn{1}{c}{ Komponen } & \multicolumn{1}{c}{ Kandungan (\%) } \\
\hline Protein & 22,63 \\
Serat & 6,81 \\
Air & 5,24 \\
\hline
\end{tabular}

Berdasarkan hasil analisa kimia menunjukkan bahwa biji ketapang memiliki kandungan protein yang cukup tinggi yaitu mencapai $22,63 \%$ sedangkan serat kasarnya mencapai $6,81 \%$. Meskipun agak berbeda dengan hasil penelitian terdahuluyaitu bahwa kandungan proteinnya $25,3 \%$ dan serat $11,75 \%$ (Lia, dkk., 2010), adanya perbedaan kandungan zat gizi pada biji ketapang tersebut kemungkinan disebabkan oleh perbedaan kandungan unsur hara tanah, cara pemupukan, kesuburan tanah dan sebagainya.

\section{Hasil analisa kimia}

Pada penelitian ini dilakukan analisa kimia yang meliputi analisa kadar air, protein dan serat kasar. Hasil analisa kimia stik yang dihasilkan dari percampuran tepung dengan tepung biji ketapang dapat dilihat pada Tabel 3.
Tabel 3. Hasil analisa kimia stik biji ketapang

\begin{tabular}{cccc}
\hline $\begin{array}{c}\text { Penggunaan } \\
\text { Tepung : } \\
\text { Tepung Biji } \\
\text { Ketapang (g) }\end{array}$ & $\begin{array}{c}\text { Kadar air } \\
(\%)\end{array}$ & $\begin{array}{c}\text { Kadar } \\
\text { Protein } \\
(\% \mathrm{db})\end{array}$ & $\begin{array}{c}\text { Kadar } \\
\text { Serat } \\
(\% \mathrm{db})\end{array}$ \\
\hline 100:00:00 & $4,21 \mathrm{a}$ & $12,06 \mathrm{e}$ & $3,38 \mathrm{e}$ \\
\hline $90: 10: 00$ & $3,98 \mathrm{~b}$ & $13,67 \mathrm{~d}$ & $3,47 \mathrm{~d}$ \\
\hline $80: 20: 00$ & $3,67 \mathrm{c}$ & $15,10 \mathrm{c}$ & $3,64 \mathrm{c}$ \\
\hline $70: 30: 00$ & $3,44 \mathrm{~d}$ & $16,33 \mathrm{~b}$ & $3,84 \mathrm{~b}$ \\
\hline $60: 40: 00$ & $3,25 \mathrm{e}$ & $17,61 \mathrm{a}$ & $4,79 \mathrm{a}$ \\
\hline
\end{tabular}

Keterangan : Angka yang diikuti dengan notasi huruf yang sama dalam satu kolom menandakan antar perlakuan tidak berbeda nyata pada taraf signifikansi 5\%.

Air

Berdasarkan hasil uji statistik pada taraf signifikansi 5\% menunjukkan bahwa substitusi tepung biji ketapang berpengaruh secara nyata terhadap kadar air stik yang dihasilkan. Semakin besar substitusi tepung biji ketapang maka kadar air stik yang dihasilkan semakin kecil. Hal ini diduga bahwa penurunan kandungan air dalam stik disebabkan adanya perbedaan kadar air awal dari tepung terigu dengan tepung biji ketapang. Kadar air tepung terigu mencapai $12 \%$ lebih besar dibandingkan dengan kadar air tepung biji ketapang yaitu berkisar 5,25\%, sehingga semakin besar substitusi tepung biji ketapang maka kadar air stik yang dihasilkan semakin kecil. Pola perubahan kadar air stik selengkapnya dapat dilihat pada Gambar 1.

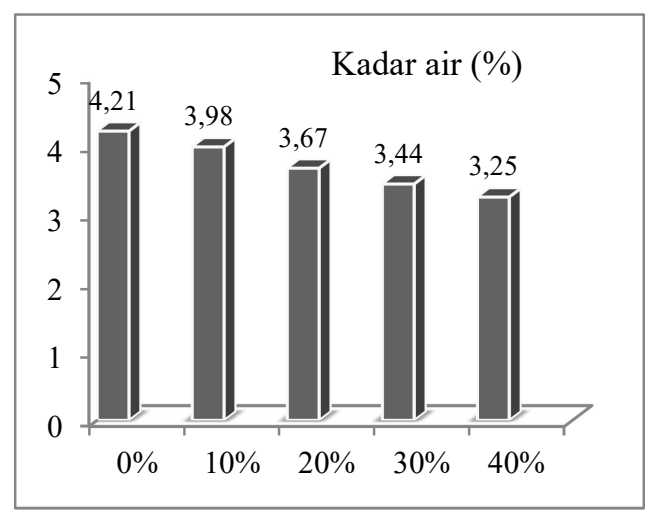

Gambar 1. Grafik kadar air stik

\section{Protein}

Substitusi tepung terigu dengan tepung biji ketapang pada pembuatan stik berpengaruh 
secara nyata terhadap kadar protein stik yang dihasilkan seperti terlihat pada Tabel 7. Semakin besar substitusi tepung biji ketapang, maka kadar protein stik yang dihasilkan semakin besar. Kenaikan kadar protein stik tersebut diduga berasal dari kandungan protein tepung biji ketapang. Menurut Lia, dkk., (2010) kadar protein biji ketapang $(25,3 \%)$ dan hasil analisa tepung biji ketapang yang digunakan sabagai bahan subtitusi dalam pembuatan stik mencapai $22,63 \%$, sedangkan kadar protein tepung terigu $8,90 \%$. Pola perubahan kadar protein stik selengkapnya dapat dilihat pada Gambar 2.

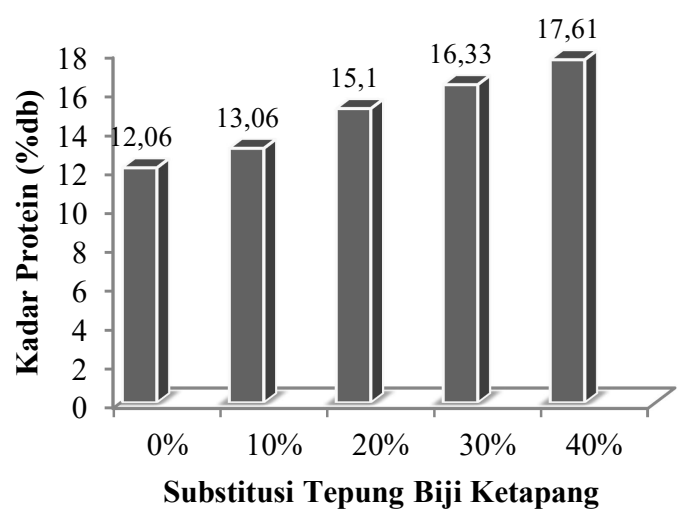

Gambar 2. Grafik kadar protein stik

\section{Serat}

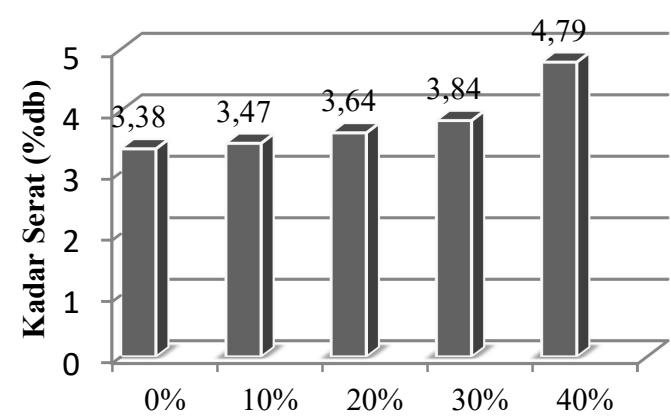

Substitusi Tepung Biji Ketapang

Gambar 3. Grafik kadar serat stik

Hasil analisa kimia serat menunjukkan bahwa substitusi tepung biji ketapang berpengaruh secara nyata terhadap kandungan serat kasar stik yang dihasilkan. Pada Tabel 7 menunjukkan bahwa semakin besar substitusi tepung biji ketapang pada pembuatan stik, maka kandungan serat kasar stik semakin besar.
Peningkatan kandungan serat kasar ada kemungkinan merupakan sumbangan dari tepung biji ketapang karena kandungan serat pada tepung biji ketapang lebih besar dibandingkan dengan tepung terigu.Pola perubahan kadar serat stik selengkapnya dapat dilihat pada Gambar 2

\section{Warna}

Hasil uji statistik organoleptik warna seperti terlihat pada Tabel 4, menunjukkan bahwa substitusi tepung terigu dengan tepung biji ketapang pada pembuatan stik berpengaruh secara nyata terhadap warna stik yang dihasilkan. Semakin besar subtitusi tepung biji ketapang, maka warna stik yang dihasilkan berwarna coklat. Terbentuknya warna coklat disebabkan telah terjadinya reaksi Maillard (non enzimatis) yaitu reaksi antara gugus aldehid dan keton dari gula dengan komponen asam amino membentuk senyawa melanoidin yang berwarna coklat (Winarno, 1992). Reaksi ini akan menghasilkan senyawa melanoidin yang berwarna coklat, sehingga semakin besar substitusi tepung biji ketapang maka warna stik yang dihasilkan akan semakin coklat. Hal ini sesuai dengan uji kimia yang menunjukkan bahwa semakin besar substitusi tepung biji ketapang maka kadar protein stik semakin besar.Pola perubahan warna stik selengkapnya dapat dilihat pada Gambar 4.

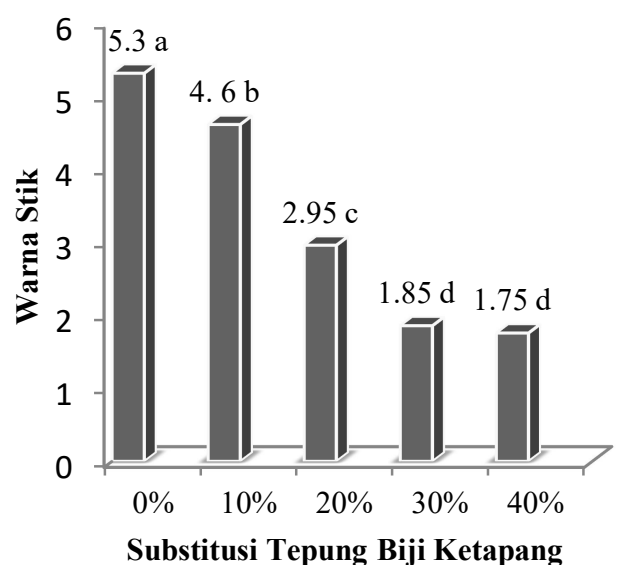

Gambar 4. Grafik nilai warna stik

\section{Rasa}

Rasa adalah salah satu parameter mutu yang dapat ditangkap oleh indera perasa. 
Berdasarkan hasil uji rasa stik, bahwa semakin besar subtitusi tepung biji ketapang maka stik yang dihasilkan semakin teras tepung biji ketapang. Panelis memberikan rasa tepung biji ketapang pada konsentrasi $20 \%$. Pola perubahan rasa stik selengkapnya dapat dilihat pada Gambar 5.

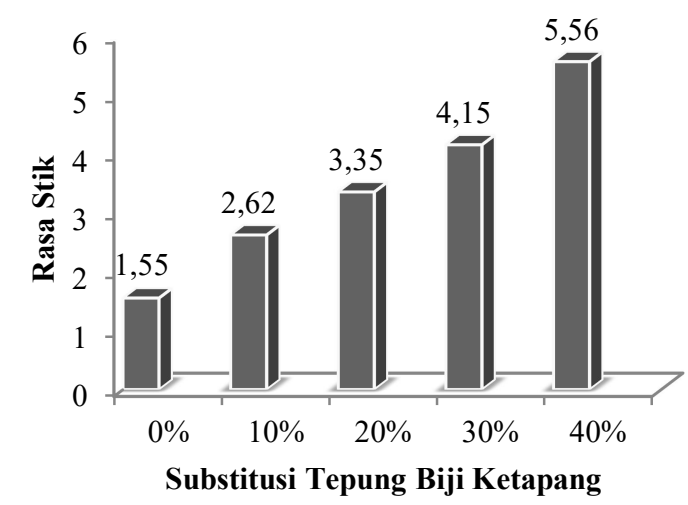

Gambar 5. Grafik nilai rasa stik

\section{Kerenyahan}

Berdasarkan hasil analisa organolpetik terhadap kerenyahan stik menunjukkan bahwa subtitusi tepung biji ketapang yang semakin besar berpengaruh secara nyata terhadap kerenyahan stik yang dihasilkan.

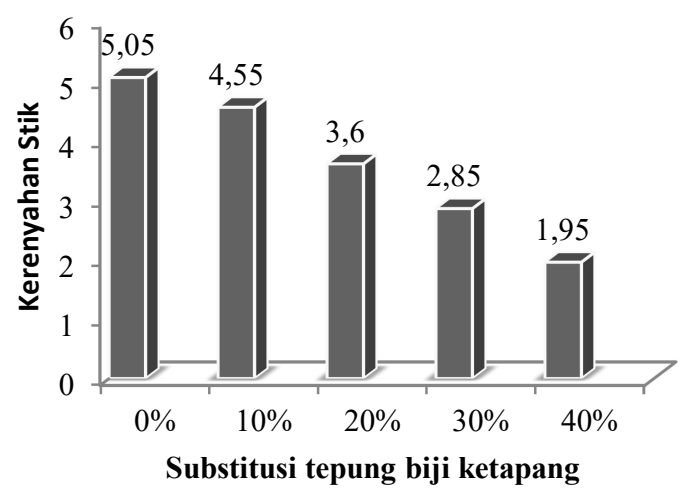

Gambar 6. Grafik nilai kerenyahan stik

Semakin besar substitusi tepung biji ketapang akan menghasilkan stik yang tidak renyah. Hal ini disebabkan tepung biji ketapang tidak mengandung gluten dan mengandung serat relatif cukup tinggi, sehingga dapat berpengaruh terhadap sifat dinding sel dan rongga-rongga udara stik yang terbentuk. Hal ini mengakibatkan stik menjadi tidak renyah. Pola perubahan kerenyahan stik selengkapnya dapat dilihat pada Gambar 5.

\section{Kesukaan}

Berdasarkan hasil analisa organoleptik kesukaan (Tabel 4) menunjukkan bahwa stik dengan substitusi tepung biji ketapang yang semakin besar tidak disukai oleh panelis. Hal tersebut berkaitan dengan kerenyahan, warna dan rasa stik yang dihasilkan. Atas dasar kesukaan secara keseluruhan tersebut, maka panelis masih menyukai stik yang dihasilkan sampai pada subtitusi tepung biji ketapangmaksimal 20\% $(3,52)$ dengan kriteria stikberwarna kuning kecoklatan $(2,95)$, agak terasa tepung terigu $(3,35)$, dan renyah $(3,60)$. Pola perubahan kesukaan stik selengkapnya dapat dilihat pada Gambar 6.

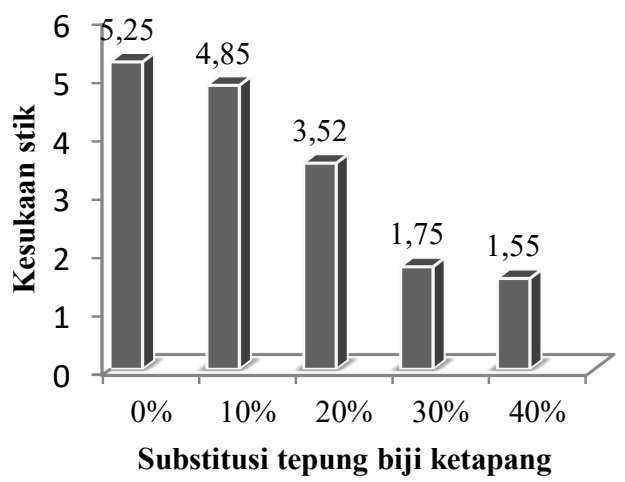

\section{Gambar 7. Grafik nilai kesukaan stik}

Sifat organoleptik terhadap stik biji ketapang yang dihasilkan meliputi warna, rasa, kerenyahan dan kesukaan secara keseluruhan. Hasil uji organoleptik dapat dilihat pada Tabel 4. 
Tabel 4. Hasil uji sensoris stik

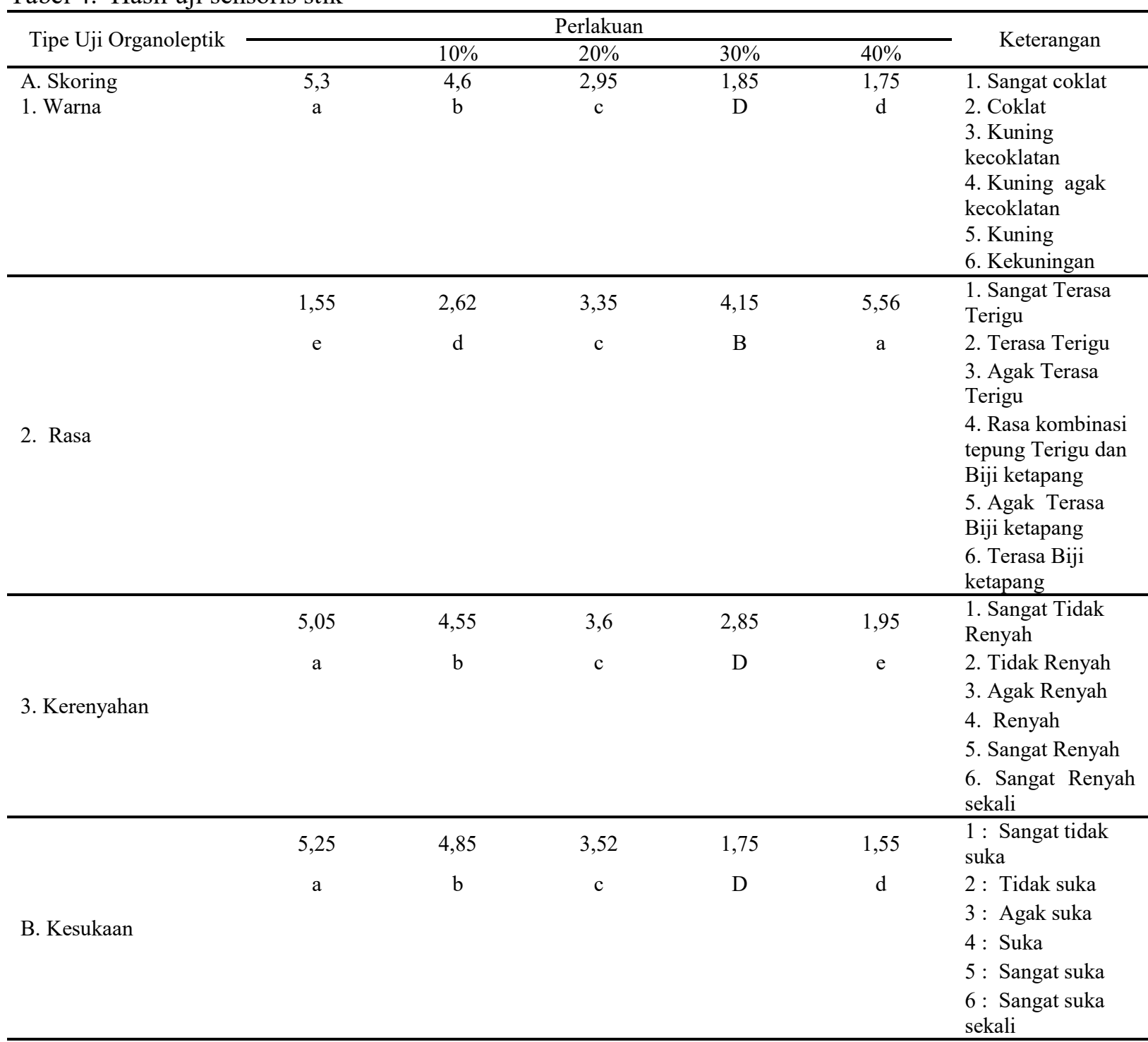

\section{Kesimpulan}

Berdasarkan hasil penelitian, maka dapat disimpulkan bahwa substitusi tepung terigu dengan tepung biji ketapang berpengaruh terhadap stik yang dihasilkan,yaitu dapat menurunkan kadar air stikdan meningkatkan kadar protein dan serat stik. Berdasarkan parameter kimia dan organoleptik, maka panelis masih menyukai stik yang dihasilkan sampai pada subtitusi tepung biji ketapang $30 \%$ yaitu dengan nilai 3,52 dan kriteria stik yang dihasilkan mempunyai kadar air 3,67\%, kadar protein $15,10 \% \mathrm{db}$, kadar serat $3,64 \% \mathrm{db}$,warna kuning kecoklatan $(2,95)$, agak terasa tepung terigu $(3,35)$, dan renyah $(3,60)$.

\section{Daftar pustaka}

Anonim, 1981, Daftar Komposisi Bahan Makanan, Bhratara Karya Aksara, Jakarta.
Anonim, 1981b, Pedoman Pembuatan Roti dan Kue, Penerbit Jambatan, Jakarta

Darmawan Eman, 2011, Pemanfaatan Kacang Merah (Phaseolus vulgaris L) Sebagai Sumber Protein dan Vitamin A Altenatif pada Produk Stik), Prosiding Seminar Nasional Hasil Penelitian Dosen Kopertis Wilayah V DIY, Yogyakarta.

De Man, J.M., 1976. Principles qf Food Chemlstry. The Avi Publishing Company, Inc., Westport, Connecticut.

Hodge, J.E. dan Osman, E.M., 1976.Carbohydrates. (dalam Principles in Food, Science Part 1: Food Chemlstry, Fennema, OR., Ed.) Marcel Dekker Inc., New York.

Kartika B. Puji Hastutik dan W. Supartono, 1998, Pedoman Uji Inderawi Bahan Pangan, PAU Pangan dan Gizi, UGM, Yogyakarta. 
Lia Nurul Husnah, Meivitasari dan Pradekatiwi, 2010, Tempe dari Biji Ketapang, Skripsi,Fakultas MIPA UNY, Yogyakarta.

Meyer, L.H., 1973. Food Chemlstry. Reinhold Publishing Company, New York.

Muchroji, 2005, Aneka Kripik, PPG, Cianjur

Muchtadi, D, 1989, Evaluasi Nilai Gizi Pangan, PAU, Pangan dan Gizi IPB, Bogor.

Sarwono, B, Bambang Agus Murtijo dan Ani Daryanto, 1985, Pengawetan dan Manfaat Telur, PT.Penerbit Swadaya.

Sudarmaji Slamet, Bambang Haryono, dan Suhardi, 1984, Prosedur Analisa Untuk Bahan Makanan dan Pertanian, Liberty, Yogyakarta.

Sultan W.J, 1969, Practical Baking, The Avi Publishing Co, Inc, Wesport Connecticut.

Winarno F.G, 2002, Kimia Pangan dan Gizi, PT. Gramedia Pustaka Utama, Jakarta. 